BIAEOSTOCKIE

TEKl

HISTORYCZNE

TOM 7/2009

ISSN 1425-1930

\title{
Krzysztof Michałek 31 VIII 1955 - 24 XI 2009
}

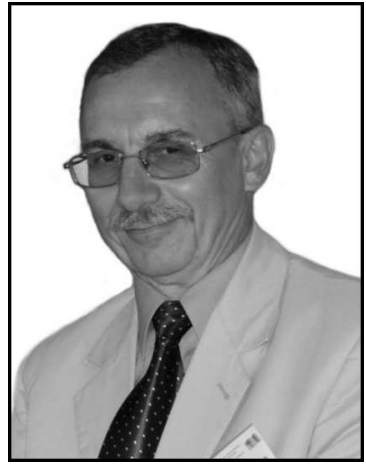

Okrutny los przedwcześnie przerwał niezwykle twórcze życie wielkiego Uczonego, wspaniałego Kolegi i wyjątkowego Człowieka. 24 listopada 2009 r. zginął w wypadku samochodowym Profesor dr hab. Krzysztof Michałek, wybitny historyk, utalentowany i ceniony wykładowca akademicki, niezwykle zasłużony dla rozwoju badań amerykanistycznych w Polsce. Pożegnaliśmy Go w ceremonii pogrzebowej, która miała miejsce w Jabłonnie k/Warszawy w dniu 30 listopada b.r. W uznaniu wybitnych zasług dla nauki polskiej Profesor pośmiertnie odznaczony został przez Prezydenta RP Lecha Kaczyńskiego Krzyżem Kawalerskim Orderu Odrodzenia Polski.

Krzysztofa Michałka poznałam wiele lat temu, kiedy zaczęłam uczęszczać na prowadzone przez Prof. dr hab. Andrzeja Bartnickiego seminarium doktorskie poświęcone historii powszechnej. Zapamiętałam Go od razu, bowiem w naszym gronie już wtedy wyróżniał się oczytaniem, elokwencją, spokojem i skromnością, która pozostała Jego nieodłączną cechą, swoistym ,znakiem firmowym”. Był zawsze nienagannie przygotowany i niesamowicie zdyscyplinowany. Był też skory do dyskusji i potrafił zadawać rozliczne pytania, rozbudzając intelektualnie kolegów i nadając ton wielu naszym niekończącym się dyskusjom. Od pierwszych spotkań seminaryjnych regularnie doświadczałam życzliwości Krzysztofa. Niedługo potem udało się nam trochę lepiej poznać i nasza znajomość przekształciła się w wieloletnią przyjaźń i pełne obustronne zaufanie. Poczytuję to za wielki dar losu.

Spotkania seminaryjne w niezwykle gościnnym domu państwa Kaliny i Andrzeja Bartnickich na Grotach były to dla nas, uczniów Profesora, bardzo ważne, a Krzysztof był ich głównym spiritus movens. Tam też - w prawdziwie rodzinnej atmosferze - rodziły się najlepsze pomysły i plany wspólnych przedsięwzięć, jak Encyklopedia historii Stanów Zjednoczonych czy pięciotomowa Historia Stanów Zjednoczonych, których - obok Profesora Andrzeja Bartnickiego - prawdziwym 
filarem był właśnie Krzysztof, inicjator wielu nowatorskich pomysłów i zawsze chętny do podejmowania nowych zadan, prawdziwy tytan pracy.

Krzysztof Michałek był kimś zupełnie wyjątkowym, choć być może nie zdawaliśmy sobie z tego sprawy, póki był pośród nas, taki swój, sympatyczny i bardzo bliski. Wykazywał niezwykłą życzliwość dla otoczenia, był uczynny, koleżeński, a w kontaktach z ludźmi mu bliskimi - bardzo ciepły i serdeczny. Osobom, które go słabo znały, mógł się wydawać niezbyt rozmowny, zdystansowany i niedostępny czy nawet zarozumiały. Nic bardziej błędnego! Krzysztofa cechowała niezwykła otwartość, tolerancja i życzliwość. Bez problemu udawało się Go „rozczmuchać”, kiedy przebywał w gronie osób zaprzyjaźnionych. Był nie tylko rozmowny, ale potrafił być i ... prawdziwym gawędziarzem. Cechowała Go niespożyta energia, witalność, otwartość i ciekawość świata. Był też osobą niezwykle rodzinną. Lubił podróże w czasie i przestrzeni, wiele podróżował, snując plany dalszych wyjazdów w towarzystwie ukochanej żony Maliny. Był człowiekiem spełnionym i szczęśliwym - zasadził drzewo, miał syna i zbudował wymarzony piękny dom, będący dla Niego i Jego najbliższych enklawą rodzinnej harmonii, spokoju, elegancji i komfortu. Progi Jego domu i Jego żony stały zawsze otworem dla przyjaciól, do których - co poczytuję jako wielkie szczęście i ogromny zaszczyt - zostałam zaliczona. Spotkania w tym gościnnym domu $\mathrm{z}$ uroczym ogrodem zachowam $\mathrm{w}$ pamięci jako coś szczególnego i niepowtarzalnego.

Przeglądam fotografie $\mathrm{z}$ ważnych wydarzeń w moim życiu, z rozmaitych ciekawych spotkań, pobytów w Stanach Zjednoczonych, udziału w konferencjach, a także uczestnictwa w prywatnych, bardzo osobistych uroczystościach, niezobowiązujących rozmowach i inspirujących dyskusjach. Wszystkie one przywołują najlepsze wspomnienia o Krzysztofie, wspólnych inicjatywach badawczych, podróży do Wielkiego Kanionu, spotkaniach w Bloomington, Waszyngtonie, Berlinie, Luksemburgu... Był świetnym kompanem wielu wspólnych podróży, znakomitym przewodnikiem i interlokutorem. Cechowało go wiele przeróżnych talentów i tak rzadkich już dzisiaj walorów moralnych. Był sumienny, rzetelny, niezwykle życzliwy ludziom. Nie znał zazdrości i zawiści, zawsze potrafił cieszyć się szczęściem innych, a w ludziach widział to, co najlepsze. W trudnych chwilach zawsze było można na Niego liczyć. Mimo pozycji, którą osiągnął, mimo zaszczytów, które go zasłużenie spotkały, moralnie nie zmienił się przez te 30 lat, w których dane było mi Go znać i spotykać. Zawsze pozostał sobą serdeczny, bezpośredni, lojalny, uczciwy, skromny i prawy.

Z Instytutem Historycznym Uniwersytetu Warszawskiego związany był Krzysztof Michałek przez ponad 30 lat, łącząc aktywność naukową i dydaktyczną z pracą organizacyjną. Już od czasów studenckich interesował się historią powszechną XIX i XX wieku, ze szczególnym uwzględnieniem dziejów Stanów Zjednoczonych. Rezultatem tych głębokich fascynacji i pasji były prace: magisterska, doktorska i habilitacyjna oraz towarzyszące im kolejne publika- 
cje. Trwałość owych zainteresowań badawczych wpłynęła na fakt, że Jego dorobek naukowy jest nie tylko rozległy pod względem liczby publikacji, ale przede wszystkim cechuje go niezwykła dociekliwość i oryginalność tez oraz wysoki poziom naukowy i znakomity warsztat. Zainteresowania naukowe Krzysztofa Michałka ewoluowały z czasem od dyplomacji konfederacji i dziejów politycznych Południa amerykańskiego oraz wojny secesyjnej (Dyplomaci i okręty. Z dziejów polityki zagranicznej Skonfederowanych Stanów Ameryki, 1861-1865, Warszawa 1987; Pod banderami Unii i Konfederacji. Wojna secesyjna, 1861-1865 na morzach $i$ rzekach, Warszawa 1996) do historii politycznej i intelektualnej na przełomie XIX i XX w. (Poza granice kontynentu. Teoria pogranicza Fredericka Jacksona Turnera a idea ekspansji dalekowschodniej $w$ amerykańskiej polityce zagranicznej, 1893-1922, Warszawa 1992). Książki te, jak i liczne artykuły publikowane $\mathrm{w}$ fachowych periodykach, spotkały się $\mathrm{z}$ wysokimi ocenami w środowisku, a młody badacz szybko znalazł się w ścisłym gronie najwybitniejszych historyków amerykanistów, cenionych w kraju i za granicą. Regularnie publikował m.in. w „Mówią Wieki”, „Kwartalniku Historycznym”, „Przeglądzie Humanistycznym”, „Przeglądzie Historycznym”, „American Studies” oraz „Dziejach Najnowszych”. Z ostatnim pismem z czasem związał się ścisłą współpracą. Od 1997 r. zasiadał w jego Komitecie Redakcyjnym, a od 1998 r. został członkiem Redakcji.

Krzysztof Michałek stopniowo poszerzał pole badawcze, zarówno pod względem chronologicznym, jak i tematycznym, o czym dobitnie świadczą kolejne Jego publikacje. Z czasem chętniej podejmował zagadnienia XX-wiecznej historii Stanów Zjednoczonych, a także kwestii współczesnych Ameryki. Warto przypomnieć Jego niezwykle udane syntezy, cieszące się wielkim zainteresowaniem i poczytnością kolejnych roczników studentów, dla których stały się nie tylko użyteczną, ale przede wszystkim frapującą lekturą. Mam tu na myśli przede wszystkim ,zaczytywane” przez rzesze czytelników dwa tomy - Na drodze ku potędze. Historia Stanów Zjednoczonych Ameryki, 1861-1945 (Warszawa 1991 oraz Warszawa 1993 - II wydanie), Mocarstwo. Historia Stanów Zjednoczonych Ameryki, 1945-1992 (Warszawa 1995), a także obszerną, wszechstronną, ostatnią z Jego książek - Amerykańskie stulecie. Historia Stanów Zjednoczonych, 1900-2001, Warszawa 2004. Syntezy są doniosłym osiągnięciem naukowym Krzysztofa Michałka i na trwałe weszły do polskiej amerykanistyki.

Wspominając dorobek pisarski Krzysztofa Michałka, nie można nie zauważyć Jego osobistego zaangażowania i ogromnego wkładu w przedsięwzięciach zespołowych. Był, można by rzec, typowym uczonym-samotnikiem, który mimo to $\mathrm{z}$ zadziwiającą umiejętnością potrafił też pracować $\mathrm{w}$ zespole i organizować jego poczynania. Okazał się prawdziwym mistrzem pracy zespołowej, o czym przekonałam się osobiście wielokrotnie, a czego świadectwem pozostały ważne w tym zakresie publikacje. Warto szczególnie podkreślić, że z Jego wielkim udziałem - powstały pionierskie, niezwykle ważne i wręcz unikalne prace, do- 
tyczące dziejów USA: Encyklopedia historii Stanów Zjednoczonych Ameryki. Dzieje polityczne (od Deklaracji Niepodległości do wspótczesności), Warszawa 1992 oraz pięciotomowa Historia Stanów Zjednoczonych Ameryki, 1607-1996, pod red. Andrzeja Bartnickiego i Donalda T. Critchlowa, Warszawa 1995. Krzysztof Michałek był autorem ponad 350 haseł w Encyklopedii i czterech rozdziałów w tomie III i IV Historii Stanów Zjednoczonych, jak i współredaktorem tomu V. Miał więc niekwestionowany duży udział w tych inicjatywach, będących ważnymi osiągnięciami polskiej amerykanistyki. Pod Jego redakcją ukazał się także interesujący i użyteczny zbiór źródeł do historii Stanów Zjednoczonych p.t. A Selection of Sources in Political and Cultural History of the United States of America (From Colonization to 1945), Warsaw 1994.

W latach 90. ubiegłego wieku Krzysztof Michałek zaangażował się także w prace organizacyjne w polskim i międzynarodowym ruchu amerykanistycznym. W latach 1990-1992 był członkiem zarządu Polskiego Towarzystwa Studiów Amerykanistycznych (PTSA), a w latach 1991-96 także członkiem zarządu European Association for American Studies (EAAS) oraz wiceprezesem American Studies Network w latach 1996-1998. Z niespotykaną energią i wielkim zaangażowaniem podejmował kolejne zadania i wyzwania, łącząc je z dotychczasowymi jakże licznymi obowiązkami. Wyrazem uznania dla osiągnięć i pozycji Krzysztofa Michałka w amerykanistyce było powierzeniu Mu funkcji wiceprzewodniczacego 50 ${ }^{\text {th }}$ International Congress of Americanists. Obrady Kongresu, które odbyły się w Warszawie w dniach 10-14 lipca 2000 roku z udziałem blisko 1600 osób z całego świata, były w dużej mierze Jego zasługą i wielkim sukcesem. Był z tego dumny, ale z wrodzoną skromnością nie mówił o swoim sukcesie, lecz polskiej amerykanistyki. Stał się jej widocznym, niekwestionowanym filarem.

Amerykanie bardzo wysoko cenili Krzysztofa zarówno za Jego badania, udział w konferencjach, jak i prace organizacyjne. Przez lata był tzw. International Contributing Editor w prestiżowym periodyku Journal of American History, promując tam osiągnięcia polskiej amerykanistyki. Jako wicedyrektor Polish Studies Center (PSC) w Indiana University w Bloomington dał się poznać od najlepszej strony zarówno jako doskonały administrator, jak i znakomity nauczyciel akademicki oraz badacz. Przez blisko dwa pracowite i jakże twórcze lata (wrzesień 1992 - czerwiec 1994) organizował pracę Ośrodka, przyczyniając się - wbrew pierwotnym zamierzeniom ówczesnych władz, by „wygaszać” współpracę - do rozwoju wymiany stypendialnej pomiędzy Uniwersytetem Warszawskim a uniwersytetami amerykańskimi. Popularyzował Polskę i sprawy polskie za oceanem, udzielając się w mediach i organizując zbiórkę pieniędzy na Ośrodek. Jego zaangażowanie i systematyczna praca, by nie rzec misja, przyniosły spodziewane rezultaty. Cieszył się z tego i potrafił ze swadą opowiadać o tych latach spędzonych w życzliwym i bliskim mu Bloomington, gdzie zbudował sieć kontaktów i przyjaźni, które przetrwały do dzisiaj. 
Krzysztof znalazł też czas, dzięki tylko Jemu znanej perfekcji organizacyjnej i niezwykłej pracowitości, na własne badania, które uwieńczone były kolejnymi publikacjami. Dał się poznać również studentom amerykańskim jako utalentowany nauczyciel akademicki. W Departamencie Historii, który znał z wcześniejszego pobytu na wymianie stypendialnej pomiędzy Uniwersytetem Warszawskim a Indiana University, odnowił kontakty, zwłaszcza z Profesorem Robertem Ferrellem, wybitnym historykiem, znawcą dziejów ojczystych, prezydentury i dyplomacji Stanów Zjednoczonych. Krzysztof Michałek prowadził tam cieszące się ogromnym zainteresowaniem trzy popularne kursy: z amerykańskiej polityki zagranicznej w czasie prezydentury Harrye'go S. Trumana, historii społecznej lat 1920-tych oraz dziejów amerykańskiego Południa w czasie wojny secesyjnej. Ostatnie $\mathrm{z}$ tych zajęć miały charakter eksperymentalny, bowiem dotyczyły tzw. historii alternatywnej. Zajęcia Profesora z Polski, wykładającego amerykańską historię dla amerykańskich studentów w środku Ameryki ... były same w sobie - jak sądzę - intrygującym eksperymentem dla obu stron. Potrafił ich zainteresować, pobudzić intelektualnie i wiele nauczyć o ich rodzimej historii. Zawsze po zajęciach otaczali Go studenci z mnóstwem dodatkowych pytań, czując siłę argumentów i autorytetu Profesora z Polski.

Niedługo po powrocie ze Stanów Zjednoczonych Krzysztof Michałek, jako uznany badacz i doświadczony organizator, otrzymał kolejne zadanie i wyzwanie, a mianowicie kierowanie Ośrodkiem Studiów Amerykańskich UW (OSA). Jako Dyrektor Ośrodka (luty 1995 - wrzesień 1999) i przewodniczący Rady Naukowej (październik 1999 - wrzesień 2002) wniósł On ogromny wkład w jego bezprecedensowy rozkwit. Był szefem wymagającym, przed którym czuło się respekt, ale też każdy z Nim kontakt był niezwykle pożyteczny i twórczy. Niespożyta energia, coraz to nowe pomysły dydaktyczne i projekty naukowe przyczyniły się do rozbudowy OSA oraz najlepszej amerykanistycznej biblioteki w tej części Europy. To w dużej mierze Jego osobiste kontakty i autorytet przyciągały do Ośrodka znakomitych specjalistów, chętnie też gościnnie występujące krajowe i zagraniczne osobistości. Dyrektor zainicjował cykliczne spotkania w Ośrodku pod nazwą FORUM, w ramach którego od stycznia 1997 roku wykłady wygłaszali wybitni przedstawiciele polskiego i amerykańskiego życia politycznego oraz gospodarczego. Tytułem przykładu warto odnotować choćby wystąpienia byłego sekretarza stanu Henry'ego Kissingera, ambasadorów USA w Polsce Nicholasa Rey'a i Daniela Frieda, doradcę ds. bezpieczeństwa narodowego Zbigniewa Brzezińskiego, także prezesa NBP Hanny Gronkiewicz-Waltz czy ministra obrony narodowej Janusza Onyszkiewicza. Każde takie spotkanie było ważnym wydarzeniem uniwersyteckim, co zapamiętali z wdzięczności, dumą i satysfakcją zarówno studenci, jak i pracownicy OSA. Były to znakomite działania promocyjne samego Ośrodka i studiów amerykanistycznych, cieszących się wówczas coraz większym zainteresowaniem. Znany wtedy powszechnie, stał się, w dużej mierze 
dzięki inicjatywom Dyrektora, placówką ekspercką kształtującą opinie w odniesieniu do spraw amerykańskich.

Krzysztof Michałek był też znakomitym dydaktykiem, a Jego zajęcia zawsze budziły duże zainteresowanie i prawdziwe uznanie studentów. Na Jego wykłady, seminaria magisterskie i doktorskie uczęszczali studenci i doktoranci, zainteresowani tematyką amerykanistyczną, urzeczeni Jego głęboką wiedzą i profesjonalizmem. Krzysztof był znakomitym wykładowcą i świetnym mówcą. Jego wykłady - niezwykle pedantyczne, precyzyjne i zawsze na wysokim poziomie merytorycznym - zapamiętali wszyscy studenci, którzy mieli szansę w nich uczestniczyć. $\mathrm{Z}$ czasem coraz więcej z nich rozumiało, że był to przywilej i starali się skorzystać z tej wyjątkowej sposobności. Nietuzinkowy styl i sposób opowiadania oraz pasja, którą Profesor potrafił zarazić słuchaczy, zyskały mu z biegiem lat oddaną rzeszę wiernych studentów i doktorantów. Był ceniony, szanowany i lubiany przez studentów, których też bardzo lubił i miał z nimi dobry kontakt. Był nauczycielem bardzo wymagającym, może i surowym, ale sprawiedliwym. Zawsze, mimo swego nieraz napiętego programu i licznych obowiązków, miał czas dla uczniów, którzy zwracali się do Niego z zapytaniem czy prośbą o poradę $w$ sprawach merytorycznych. Wspierał ich poczynania na niwie naukowej, inspirował i zachęcał do dalszych poszukiwań badawczych, sekundując w podejmowaniu ambitnych planów. Z biegiem lat Jego seminarium doktorskie bardzo się rozrosło liczebnie, tworząc zalążki prawdziwej szkoły. Wypromował wielu magistrów i doktorów, z których część zdąża do samodzielności naukowej.

Rezultatem prac badawczych Krzysztofa Michałka były monografie, syntezy oraz liczne artykuły naukowe i popularnonaukowe dotyczące Stanów Z jednoczonych, ich przeszłości, jak i coraz częściej teraźniejszości. Plon prac badawczych Profesora Krzysztofa Michałka jest niezwykle obfity - kilkanaście książek oraz blisko 200 artykułów i recenzji opublikowanych w pismach krajowych i zagranicznych. Ponadto pisał On także do gazet, udzielał wywiadów, stając się świetnym popularyzatorem - w najlepszym tego słowa znaczeniu - wiedzy o Stanach Zjednoczonych w polskich mediach. Począwszy od 1994 r. w serii kilkudziesięciu audycji w Radiu BIS przybliżył słynne postacie amerykańskiej historii, zwłaszcza prezydentów i wybitnych polityków, m.in. Johna F. Kennedy'ego, Theodore'a Roosevelta, Harry'ego S. Trumana, Martina Luthera Kinga, Johna F. Dullesa, George'a Marshalla, Madeleine Albright i in. Coraz częściej brał udział w wielu programach radiowych, zarówno publicznych, jak i komercyjnych, wypowiadając się na temat amerykańskiej historii.

Krzysztof Michałek był niezwykle zdolnym i wszechstronnym specjalistą, stąd $\mathrm{z}$ wielką łatwością i równie profesjonalnie omawiał zagadnienia wojny secesyjnej, kolonizacji Zachodu, amerykańskiej prosperity w latach dwudziestych czy polityki zagranicznej USA w XIX bądź XX wieku. Coraz częściej też komentował amerykański system polityczny, zwłaszcza wyborczy, demokrację, konstytucjonalizm, globalizację świata itp. Polubiła go również kamera telewizyjna, 
czego dowodem jest fakt, że od lat stał się świetnym komentatorem i niekwestionowanym autorytetem polskich mediów w sprawach bieżącej polityki wewnętrznej i zagranicznej Stanów Zjednoczonych. Chętnie Go słuchali i oglądali wszyscy autentycznie zainteresowani USA, bowiem niezwykle precyzyjnie, profesjonalnie, rzetelnie i rzeczowo komentował najdonioślejsze zagadnienia współczesnej Ameryki, jak i jej przeszłości. Był naturalny i przekonujący w swoich wywodach. Górował nad innymi komentatorami niezwykłą precyzją i logiką wypowiedzi. Miał wielką siłę perswazji.

Pragnę też wspomnieć o niezwykłym pomyśle, który realizowaliśmy wspólnie, ale to Krzysztof był jego głównym organizatorem i filarem. Wiosną 2004 roku, po niespodziewanej i bolesnej dla nas śmierci Profesora Andrzeja Bartnickiego, podjęliśmy inicjatywę upamiętniającą dokonania naszego Mistrza. Chodziło o „utrzymanie żywej pamięci o Nim poprzez nawiązanie do Jego dokonań, które miały związek z badaniami amerykanistycznymi oraz podejściem do warsztatu naukowego". Tak zrodziły się cykliczne spotkania, organizowane w Akademii Humanistycznej im. Aleksandra Gieysztora w Pułtusku pod nazwą Forum Zaawansowanych Studiów nad Stanami Zjednoczonymi im. Profesora Andrzeja Bartnickiego. Zgodnie z pierwotnym założeniem, Forum miało stworzyć warunki dla wymiany doświadczeń doktorantów zajmujących się badaniami nad historią Stanów Zjednoczonych oraz dla merytorycznej dyskusji, także nad zagadnieniami metodologicznymi i warsztatowymi. Jednodniowe I Forum z czerwca 2004 r. miało charakter pilotażowy. Zachęceni pozytywnymi opiniami uczestników podjęliśmy próbę organizacji bardziej rozbudowanych spotkań w kolejnych latach. W Forum gościli wybitni specjaliści amerykańscy i polscy, jak również coraz liczniej doktoranci (głównie historycy, politolodzy, socjolodzy, antropolodzy) z wielu ośrodków uniwersyteckich w Polsce. W roku 2010 planowaliśmy kolejne już VII Forum...

Nagła śmierć Krzysztofa Michałka spowodowała wielką stratę dla nauki polskiej, a w szczególności tak boleśnie ugodzonej amerykanistyki, w której odgrywał od lat czołową, wybitną rolę. Miał On tylko 54 lata i był w pełni sił twórczych, planował dalsze ciekawe i ambitne przedsięwzięcia naukowe, o których rozmawiałam z Nim... dwa dni przed tragicznym wypadkiem, podczas konferencji odbywającej się w Białymstoku. Swoją obecnością i znakomitym referatem uświetnił - jak zawsze - obrady i towarzyszące im dyskusje. Wielu uczestników konferencji, a zwłaszcza studenci i doktoranci, miało niepowtarzalną okazję zetknąć się z Nim osobiście, miało niepowtarzalną i ostatnią - bo przerwaną przez okrutny los - sposobność do bezpośredniego kontaktu z wielkim Autorytetem znanym wcześniej tylko z publikacji. Jakże bolesna jest świadomość, że było to ostanie spotkanie z Profesorem, spotkanie, które już nigdy, ale to nigdy nie powtórzy się.

O Krzysztofie Michałku, tragicznie i przedwcześnie Zmarłym, bardzo trudno jest mi pisać, jako o Kimś, Kogo już nie ma wśród nas. Ciągle tak trudno 
uwierzyć... Ciągle tak trudno pogodzić się z bolesną prawdą... Jego odejście sprawiło mi wielki ból. Od ponad 30 lat był Kimś dla mnie bliskim i ważnym, był Kimś, Kogo ceniłam, podziwiałam i darzyłam szacunkiem, Kimś, na Kogo mogłam liczyć i u Kogo mogłam szukać naukowej inspiracji. W mojej pamięci pozostanie nie tylko Przyjacielem, ale i wspaniałym wzorem wielkiego Erudyty, Uczonego, który rozsławił polską amerykanistykę.

Polska nauka została boleśnie ugodzona i osłabiona, bo bez Krzysztofa już nie będzie tak samo dobra, jak wcześniej.

Halina Parafianowicz

Białystok 